\title{
Female stalking: a systematic review [Retraction]
}

The paper published by Carabellese F, La Tegola D, Alfarano E, Tamma M, Candelli C, Catanesi R in Research and Reports in Forensic Medical Science. 2012;2:31-38, contained significant amounts of uncited text from These boots are made for stalking: characteristics of female stalkers. Psychiatry (Edmont). 2008 August;5(8):37-42.

\section{Publish your work in this journal}

Research and Reports in Forensic Medical Science is an international, peer-reviewed, open access journal publishing original research, reports, reviews and commentaries on all areas of forensic medical science. The manuscript management system is completely online and includes a very quick and fair peer-review system. Visit http://www.dovepress.com/ testimonials.php to read real quotes from published authors. 